\title{
Instructional Leadership Capacity of Secondary School Science Heads of Department in Gauteng, South Africa
}

\author{
Cynthia B. Malinga, Loyiso C. Jita and Abiodun A. Bada \\ University of the Free State, South Africa \\ https://orcid.org/0000-0002-2567-6504 \\ https://orcid.org/0000-0001-6871-6820 \\ https://orcid.org/0000-0001-7540-1974
}

\begin{abstract}
Natural sciences (NS) is an amalgam of five science disciplines, but the teachers of this subject are usually generalists, or have specialised in a maximum of two of the disciplines. This poses a major challenge to heads of department (HoDs), who are expected to lead instruction in these disciplines. We investigate science HoDs' capacity to provide instructional leadership in South African secondary schools. The study was quantitative in nature and adopted the survey design. The investigation involved 77 secondary schools out of the 243 schools in the Gauteng province of South Africa. A data set from 142 participants (HoDs $=30$; teachers $=112$ ) was used to explore the capacity of science HoDs to provide instructional leadership in secondary schools, using questionnaires. The findings suggest that the capacity of science HoDs to lead instruction is limited by their inability to differentiate between curriculum management and instructional leadership and the relatively insufficient time allocated to provide instructional leadership. Unless schools and local district offices review the grouping of subjects in science departments and in the allocation of natural science teachers and HoDs, much stronger subject-based instructional leadership may potentially continue to remain a mirage. We recommend more focused subjectspecific training in natural sciences for both teachers and HoDs, and that leadership should be distributed along science disciplines.
\end{abstract}

Keywords: department head; instructional leadership; natural sciences; secondary schools

\section{Introduction}

Many high school learners, some of whom might have excelled in natural sciences in primary school, often struggle with physical sciences possibly because of the kind of foundational grounding they might have received. The fact that natural sciences combines five science disciplines and that no teacher can be a specialist 
in all of these disciplines complicates the preparation for the transition from natural sciences to physical sciences. Natural sciences is a federal subject that includes agricultural, environmental, life, and physical sciences and a geography discipline. Teachers of natural sciences are recruited as generalists that might not have specialised in any of the science disciplines; or conversely, they are specialists in one or more disciplines, but rarely are they specialists in all five of the science disciplines. Even when acknowledged as adequately qualified, in reality, it is quite impossible for natural sciences teachers to be adequately sound in all the natural sciences disciplines or subject strands. If they are generalists, the tendency is that they do not address the depth of the subject in any particular discipline (Umalusi, 2008). Teachers often focus their teaching only on what they are comfortable with ( $\mathrm{Ng}$ et al., 2015), omitting topics or sections of the syllabus that they are unfamiliar with (Wanzare, 2013). It is not that teachers are irresponsible or not accountable; rather, they need help to address their own areas of weakness. Where teachers fall short, help has to come from the school or, more specifically, the Head of Department (HoD) because of their proximity to classroom teaching and learning (Highfield, 2010).

In this paper, we unpack some of the data on science HoDs in Gauteng schools, in terms of their practices and capacity for instructional leadership to assist natural sciences teachers in the rather complex context of this blended subject. We begin with a review of literature on the roles of HoDs and then explore some definitions of instructional leadership. From the review of the literature, we develop a conceptual framework for analysing the leadership practices of the science HoDs in the selected schools, before presenting the methodology and key findings. This paper concludes with a discussion of the implications of these findings to science education systems in South Africa and makes recommendations on how the capacity of HoDs can be enhanced.

\section{Reviewed Literature and Conceptual Framework}

Literature has indicated that HoDs are better suited to lead teaching and learning (Bush et al., 2010), central to effective teaching and learning (Busher et al., 2000) and an essential link to the continuum of best practices in teaching and learning (Weller, 2001). Furthermore, HoDs are the driving force behind the achievement of school goals (Collier et al., 2002) and possess frontline knowledge of classroom issues and teacher needs (York-Barr \& Duke, 2004). Moreover, they are a missing link between efforts to improve schools and current practices (Kabeta et al., 2015; Melville et al., 2007) and are pivotal to any strategy to develop learning-centered leadership in schools (Klar, 2012). More specifically, science HoDs are mostly specialists in one or two natural sciences domains but are unlikely to be experts in all five of the natural sciences domains.

\subsection{Head of Department Role and Responsibility}

Very little is known about how HoDs go about doing their work and what their perspectives are on what their role should entail (Stephenson, 2010). Wise (2000) stated that the legitimation of the HoD's role emanates from the acceptance by members of the subject department. The HoD is generally knowledgeable about the subject and the development of school-based assessment tasks in the South 
African context. Furthermore, HoDs are expected to conduct class visits, model best practices, and provide teachers with templates and feedback on their teaching (Robinson \& Timperley, 2007). As part of their role, HoDs are also expected to set subject goals and direction and expectations for achievement (Lashway, 2002), monitor the quality of instruction and achievement levels (for both teachers and learners) and evaluate instructional practices and learning. In addition, they need to maximise the effort of the instructional organisation, conduct appraisal (Smith et al., 2013) and participate in staff recruitment. Kabeta et al. (2015) opined that HoDs perceive themselves to be practising instructional leadership more than their teachers. However, in performing these duties, HoDs face many challenges, ranging from lack of time (Glickman et al., 2018), role conflict and ambiguity (Zepeda \& Kruskamp, 2007) and limited authority to the multi-disciplinarity of the subject. This situation is no different in South Africa.

The complexity of the role of HoDs is influenced by contextual factors and is often compounded by conflicting expectations from principals and teachers (Collier et al., 2002). Part of the challenge is that HoDs have multiple roles: teacher, and administrator, manager and leader (Lai \& Cheung, 2013). Siskin (1994) suggested that the HoD role is multi-dimensional because the HoD is neither a full teacher nor a full administrator. HoDs are the interface between management and teachers, but they also represent teachers in the school management team (SMT), and they represent management in the subject-department meetings with teachers. At the same time, HoDs work within a team, for the team and lead the team (Stephenson, 2010). Some literature suggest that the HoD's time is sometimes consumed by administrative work, with many not being afforded adequate release time (Glickman et al., 2018; Ndoziya, 2014; Ng et al., 2015; Seobi \& Wood, 2016) to focus on instructional issues, thus compromising their instructional leadership capacity. Anecdotal evidence has revealed that some HoDs do not even get time to lead and influence teachers in their departments.

Natural sciences teachers are also at an interface between science at the junior secondary or middle school level and the high school level and take responsibility for aligning and ensuring conceptual progression and continuity of both human resources and key instructional goals (Lai \& Cheung, 2013). At the same time, HoDs work within a team to provide the guidance, support and development that teachers need (interact on structural issues). They also work for the team (escalating teachers' requests to the SMT, procuring and organising laboratory equipment, communicating urgent demands) and they lead the team (Stephenson, 2010). The role demands that HoDs become close to those they lead and where learning actually occurs (Aubrey-Hopkins \& James, 2002).

According to the Department of Education (DoE) guideline policy document (South Africa. DoE, 2002) that guides HoD functions and mandates in South Africa, HoDs are expected to teach $85 \%$ of the time and to dedicate only $15 \%$ of their time to HoD functions. HoDs tend to work for teachers (escalating teachers' requests to SMT, procuring and organising laboratory equipment and communicating urgent demands) rather than working with teachers, guiding 
them, and providing the support and development that teachers need (interacting on instructional issues).

HoDs have very little opportunity to lead by example, identifying and modelling good practice and sharing them with the teachers they lead. Kabeta et al. (2015) supported this assertion by opining that HoDs are not actively practising instructional leadership. It is not far-fetched therefore to suggest that HoDs could enhance their leadership practices by delegating some of the duties, depending on the task at hand, through the engagement of distributed leadership (Munje et al., 2020; Spillane et al., 2004) and the agency of the teachers. This is because leadership is one of the factors that can influence the quality of teaching and learning in schools (Kabeta et al., 2015; Lai \& Cheung, 2013). HoDs also have limited authority (Weller, 2001) to discipline and appraise teachers and they also experience strained relationships with teachers (Schmidt, 2000), especially those who are not teaching up to the expected quality of instruction and expected learning outcomes. In the next section, we discuss the structure and organisation of subject departments which have a bearing on the work of HoDs.

\subsection{Subject Departments}

The subject department is a school subsystem that is organised to minimise the workload of principals, especially secondary school principals (Aubrey-Hopkins \& James, 2002). In addition, the subject department focusses on curriculum support (Harris et al., 2001) to improve the performance of learners. The generalisation on what the department should be and what it should aim to achieve complicates the appointment of departmental leaders, with the result that leaders who do not possess the appropriate credentials are sometimes appointed (Lai \& Cheung, 2013). Unfortunately, appointment to the HoD position in South Africa is sometimes offered as a reward and anyone can apply, sometimes with little preparation to lead teaching and learning (Smith et al., 2013). Even when HoDs are appointed based on reward, they do not receive training that prepares them for the new roles they occupy, as Kabeta et al. (2015) opined. Research has focused more on the practices of HoDs or department chairs where a department houses one school subject (Brown et al., 2000; Harris et al., 2001) as opposed to a group of subjects.

In South Africa, HoDs lead departments that usually comprise a group of subjects instead of one subject only (Naicker et al., 2013). There are exceptions for bigger and core subjects such as mathematics, mathematical literacy and English - for which most learners in the school are enrolled-in which case it forms a department on its own. The opposite is true for natural science, where the HoD would be responsible for all the different science disciplines offered in the school, with each one then becoming an independent subject in high school. Anecdotal evidence has suggested that some schools may even include mathematics, mathematical literacy and technology education in their science department. In South Africa, there is no uniform grouping of subjects into departments and the demarcation of departments is school context specific (Naicker et al., 2013). In other countries, there seems to be a clear structure for the department to be subject-based, except for blended subjects such as science (Harris et al., 2001; Ng 
et al., 2015; Stephenson, 2010). Interestingly, very few countries organise their science departments in such way to include non-science subjects or even mathematics.

HoDs are not likely to have the professional capacity and expertise in all subjects offered in a federal department such as the sciences. Professional credibility (Angelle \& DeHart, 2011; Ghamrawi, 2010) is necessary for the HoD's self-esteem, but also for the teachers who are being led or influenced by the HoD. Member teachers need to have confidence and be convinced that the person who leads them has the professional expertise, skills and experience to provide the guidance and support that they need (Wanzare, 2013). This has been found to not be the case, as the HoD role tends to be limited to "final checker" of teacher reports of work done (Seobi \& Wood, 2016). It is expected that the HoD will have a proven track record and experience in the knowledge and teaching of a particular subject. Literature has reported opportunities for distributed or shared leadership in schools at multiple layers (Munje et al., 2020; Spillane et al., 2001), depending on the task at hand (Spillane et al., 2004) and the agency of the teachers (Sherer, 2008). We explore some of the credentials that are expected of the HoD by the department members and senior school leadership, and the capacity of HoDs to allocate resources and lead the department.

\subsection{Instructional Leadership}

Instructional leadership involves sharing the vision of the organisation with followers, monitoring the instruction and assessment standards, allocating resources, and reflecting on the outcome of the instruction (Lashway, 2002; Ritchie et al., 2006). According to Kabeta et al. (2015), instructional leadership is leadership that prioritises teaching and learning in school in order to improve student learning. Instructional leadership also helps lead teachers, such as HoDs, and students to reach their full potential by creating a conducive environment in which teaching and learning can take place (Kabeta et al., 2015). Lashway (2002), however, suggested that there has been a shift in instructional leadership in education. The focus used to be on the leader having a vision and sharing it with followers (coherence in improvement efforts), allocating resources (both physical and human) to instruction, managing the curriculum, monitoring lesson plans (not learning) and evaluating teachers (focus clearly not on learning). More recently, instructional leadership has been focusing more on teaching and learning. This focus includes aligning curriculum instruction and assessment standards (Robinson, 2010); professional development; using of data to make decisions on professional development, resources, and instructional practice (Brown et al., 2000); and creating a safe, secure, and conducive environment for teachers using dialogue on key issues. Using classroom data, the instructional leader can make decisions about professional development needs, interventions and grouping of learners where needed. The leadership process involves the leader's capacity to involve their colleagues collaboratively in mutual development and learning, with the aim of improving teaching and learning. The $\mathrm{HoD}$ as an instructional leader influences many of the activities listed above, and the type of leadership is also influenced by the followers (teachers). In the next section, we describe our conceptual framework for this paper. 


\subsection{Conceptual Framework}

Researchers have reported on several factors that contribute to the HoD's ability to lead instruction. These range from HoD characteristics and behaviour (Bolam \& Turner, 2003; Harris et al., 2001) and contextual factors (York-Barr \& Duke, 2004) to leadership practices such as facilitating collegiality and sharing decisionmaking (Kabeta et al., 2015). The role of the HoD is context-dependent and there is no single hymn sheet for leading a department in different schools (Ritchie et al., 2006). Harris et al. (2001) asserted that the HoD role is characterised by complexity and contingency and understanding this helps to explain how and why HoDs practise (their role) instructional leadership in the ways they do. The actions of HoDs often depend on the leader themselves, the task that needs to be performed, the departmental staff or followers and the situation (Timperley, 2005). Ng (2019) outlined three domains of instructional leadership to include defining the mission statement of the school, managing the instructional programme and promoting a positive learning climate in the school. Inculcating adequate instructional leadership can assist school leaders in the achievement of these goals, as identified in the different domains. Chambalala and Naidoo (2021) therefore opined that effective instructional leadership can successfully influence others to utilise appropriate practices with the exceptional knowledge of the relevant subject matter. It was also the view of Chambalala and Naidoo (2021) that emphasising the three domains of instructional leadership can provide a clear explanation of the functions of general instructional leadership.

This paper proposes a conceptual framework based on the provisional model (Turner \& Bolam, 1998) and the teacher leadership framework proposed by YorkBarr and Duke (2004). The framework shows how the instructional leader's characteristics and knowledge of the context and its problems can be integrated to provide leadership through effective interactions with department members and how it can influence the teaching choices (Robinson, 2010). Six major components of instructional leadership by HoDs have been identified in the literature and are discussed below. An abridged version of the conceptual framework is presented in Figure 1.

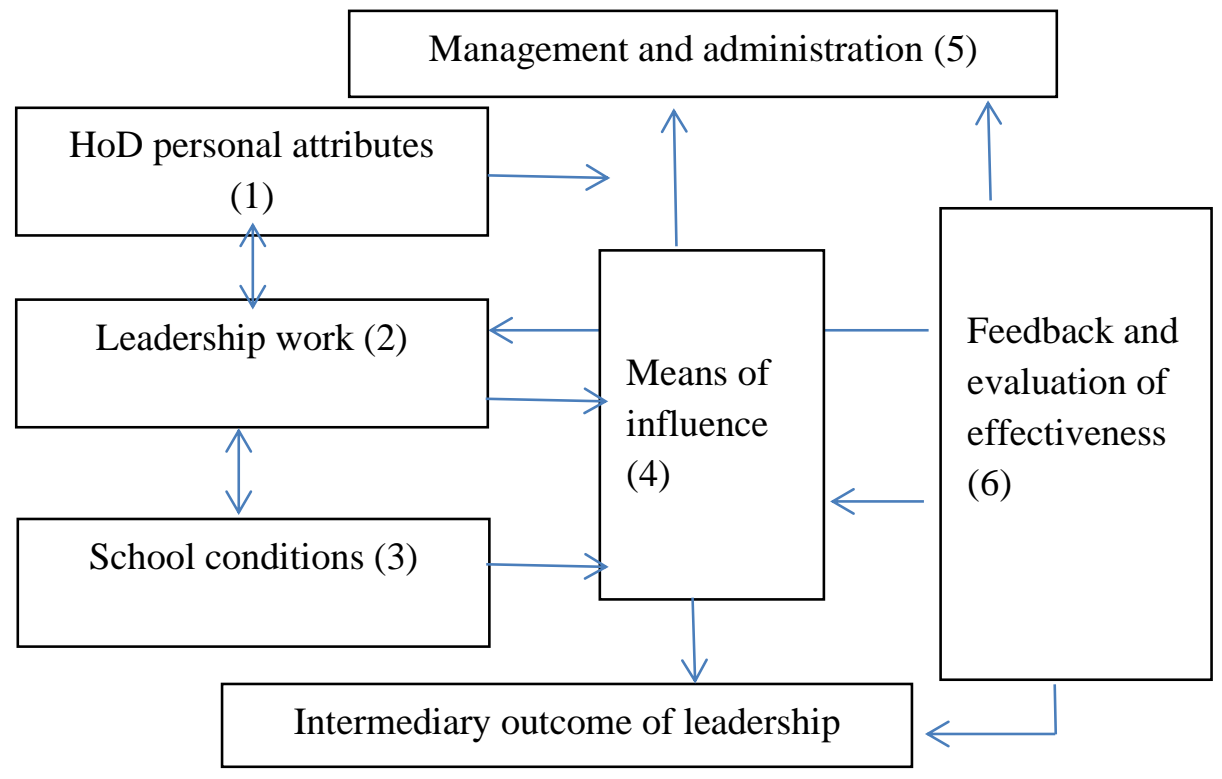

Figure 1: Abridged version of the conceptual framework for leading instruction (adapted from York-Barr \& Duke, 2004)

http://ijlter.org/index.php/ijlter 
The first component of the framework is the leader's characteristics, such as subject proficiency, experience in the subject (Stein \& Nelson, 2003), professional credibility, trustworthiness, and agency in resourcing the department. These contribute to how the department members perceive the leader $(\mathrm{HoD})$. The second component is the leadership practices, such as vision setting, building collegiality, developing teachers, building relationships, and the manner in which leadership is distributed among the department members (Hallinger, 2005).

The third component includes how the HoD negotiates their influence through the school's social, political, economic, cultural and other contextual problems (Robinson, 2010). This requires the HoD to be creative with their time and to be able to balance their own administrative and instructional leadership duties. In some schools, as explained by Klar (2012), principals assist in fostering instructional leadership practices. The fourth component looks at how the HoD influences teaching choices through setting instructional objectives, planning instruction and developing reflective practice using classroom observation and feedback sessions and action research (York-Barr \& Duke, 2004).

The fifth component is administration and management, which overarches with the role of managing people and resources. The subject department co-creates and uses routines and artefacts as a means of influencing the followers. The HoD is then expected to monitor the interaction of departmental staff through the artefacts and routines. This is the one component where many HoDs tend to spend most of their time, and it is difficult to strike a balance between this component and all four of the previous components. The sixth and final component introduces the feedback loop and evaluation of the effectiveness of leadership. It involves critical reflection by individuals, teams and the organisation as well as following up on and mentorship and dialogues about the effectiveness of instructional practices, learners' work (Lashway, 2002) and their own leadership practices.

The HoD consistently monitors the alignment of curriculum, instruction and assessment standards using data and technology to ensure accountability for performance in the classroom (Busher et al., 2000). This component provides the feedback to other components of the framework. To achieve the set goals, the findings from the evaluation have to form the basis on which the other components are modified or enhanced. The main focus of the framework is to achieve improved and effective teaching and learning practices within a department and school. Using the conceptual framework developed above, we ask the key question of our study: how is science-HoDs' instructional leadership capacity perceived by natural science teachers?

\section{Methodology}

\subsection{Research Design}

A quantitative research approach based on survey design was used to investigate science HoDs' capacity to lead instruction, in four districts in the Gauteng province of South Africa. 
The survey design, although easier to distribute to a large number of respondents and cost-effective, is not without limitations. The accuracy and honesty of answers is difficult to ascertain and the reasons for any given answer or interpretation of options cannot be solicited. To do this successfully, we used two different questionnaires to obtain data from science HoDs and teachers from the same schools. The first questionnaire was used to explore data on the instructional capacities of science HoDs, while the second questionnaire provided data on the guidance and support available to natural sciences teachers. The questions on instructional practices were asked in different ways and under different sections to elicit rich information on the capacities of HoDs to provide instructional leadership.

\subsection{Sampling Technique}

We invited 243 secondary and intermediate schools from four districts in Gauteng to take part in this study. The necessary ethical measure were observed, including seeking informed consent and providing for confidentiality of the participating schools and teachers, by using pseudonyms (McMillan \& Schumacher, 2010). The questionnaires were sent out through the district postal system. Only 77 secondary schools consented to participate and sent back their questionnaire. Included were 30 ex-Model C schools, 42 township schools and 5 independent or private schools (Table 1). The learner enrolment of the schools ranged from 429 to 1548 learners. Model C schools are fee-paying schools which are usually well resourced in terms of teaching staff and educational opportunities. The township schools are no-fee paying schools hence, they are usually less resourced when compared to the Model C schools. The independent schools are privately governed and usually received subsidy from the government.

Table 1: Participating schools

\begin{tabular}{|l|c|c|}
\hline School Type & Race & $\begin{array}{c}\text { Number of Schools } \\
\text { Participating }\end{array}$ \\
\hline Ex-Model C & Mixed & 30 \\
\hline Township & African & 42 \\
\hline Independent & Mixed & 5 \\
\hline
\end{tabular}

The size of the science departments of the participating schools varied, ranging from two to twenty teachers. Departments also varied in the subjects that the science $\mathrm{HoD}$ was responsible for. Some comprised life sciences (life sciences), physical sciences and natural sciences, while others also included mathematics, mathematical literacy and technology education. Although 112 teachers from 77 schools responded, not all HoDs from these 77 schools responded, with only 30 HoDs responding altogether (Table 2). 
Table 2: Study respondents

\begin{tabular}{|l|c|c|c|}
\hline District & $\begin{array}{c}\text { Number of } \\
\text { Schools }\end{array}$ & $\begin{array}{c}\text { Number of } \\
\text { HoDs }\end{array}$ & $\begin{array}{c}\text { Number of } \\
\text { Teachers }\end{array}$ \\
\hline B & 16 & 13 & 31 \\
\hline E & 16 & 8 & 26 \\
\hline J & 8 & 5 & 13 \\
\hline W & 37 & 4 & 42 \\
\hline Total & 77 & 30 & 112 \\
\hline
\end{tabular}

Most of the HoD respondents were middle-aged or older (Table 3). The number of female respondents (17) was slightly higher than that of male respondents (13). Most of the HoD respondents (20) had professionally qualified from teachers' colleges as opposed to those who had university qualifications (10). This could also explain the reason for middle-aged or older age range because the majority of older teachers had qualified during the era of teacher colleges of education.

Table 3: Profile of the heads of department respondents

\begin{tabular}{|c|c|c|c|}
\hline $\begin{array}{l}\text { Variable } \\
\text { Overall }\end{array}$ & Level & $\begin{array}{l}\text { Frequency } \\
\text { n }(\%)\end{array}$ & $\begin{array}{c}\text { Total }(\mathbf{N}) \\
30\end{array}$ \\
\hline Gender & $\begin{array}{c}\text { Male } \\
\text { Female }\end{array}$ & $\begin{array}{l}13(43.3) \\
17(56.7)\end{array}$ & 30 \\
\hline Age range & $\begin{array}{c}20-29 \text { years } \\
30-39 \text { years } \\
40-49 \text { years } \\
50-59 \text { years } \\
>60 \text { years }\end{array}$ & $\begin{array}{c}0 \\
4(13.4) \\
13(43.3) \\
13(43.3) \\
0\end{array}$ & 30 \\
\hline $\begin{array}{ll}\text { Subject } & \text { of } \\
\text { specialisation } & \end{array}$ & $\begin{array}{c}\text { LS } \\
\text { PS } \\
\text { NS } \\
\text { Other }\end{array}$ & $\begin{array}{c}10(33.3) \\
10(33.3) \\
7(23.4) \\
0\end{array}$ & 30 \\
\hline $\begin{array}{l}\text { Type of } \\
\text { institution where } \\
\text { qualification was } \\
\text { obtained }\end{array}$ & $\begin{array}{c}\text { Teachers college } \\
\text { University } \\
\text { Matric/unqualified }\end{array}$ & $\begin{array}{c}20(66.7) \\
10(33.3) \\
0\end{array}$ & 30 \\
\hline $\begin{array}{l}\text { Highest } \\
\text { qualification }\end{array}$ & $\begin{array}{c}\text { PTD/PTC } \\
\text { STD } \\
\text { ACE } \\
\text { Bachelor's degree } \\
\text { Post-graduate } \\
\text { Other }\end{array}$ & $\begin{array}{c}1(3.3) \\
11(36.7) \\
3(10.0) \\
4(13.3) \\
10(33.4) \\
1(3.3)\end{array}$ & 30 \\
\hline $\begin{array}{l}\text { Position held in } \\
\text { school }\end{array}$ & $\begin{array}{c}\text { HoD } \\
\text { Master/lead teacher } \\
\text { Teacher }\end{array}$ & $\begin{array}{c}26(86.7) \\
4(13.3) \\
0\end{array}$ & 30 \\
\hline
\end{tabular}

\section{Research Instrument}

We used two questionnaires to obtain data on how science HoDs' leadership capacity is perceived by natural sciences teachers. The development of the questionnaires included adapting the instructional management rating scale developed by Hallinger and Murphy (1985) from the principal focus to the 
department head focus. The Personnel Administrative Measure framework of the Department of Education (1999) was incorporated to formulate department headspecific leadership roles. Opinions of three experts in the instructional leadership field and a practitioner in the field were sought to ensure the content validity of the questionnaires. Feedback on language clarity, understanding and reliability was gathered during a pilot study that was conducted on three HoDs from township and informal settlement secondary schools. The questionnaires were distributed to 243 secondary and intermediate schools from four districts in Gauteng, South Africa. Only 142 of the 400 distributed surveys were returned, which consisted of 112 teachers and $30 \mathrm{HoDs}$. The questionnaires consisted of a Likert-type scale for responding to the items, and some background questions concerning gender and teaching experience were also included in the survey. The questionnaires were both validated and their reliability was adequately ensured.

\section{Procedure for Data Collection}

The HoDs' involvement in instructional leadership activities was rated based on how frequent the activity was practised ( $1=$ never; $5=$ always). The HoDs' general instructional leadership activities and skills were categorised, and the means of each category was taken to indicate the general trend in the subcategories. In addition to the Likert-type questions, participants also had to respond to questions on gender and teaching experience. Administration of the questionnaires was done over a period of three months.

\section{Data Analysis}

The data obtained from this investigation were analysed using descriptive statistics. This included the use of frequency counts, percentages, means, and bar charts.

\section{Findings}

Natural sciences is a conglomerate subject comprising five science disciplines, namely physical sciences, life sciences, mathematics, mathematical literacy and technology. This is not a new subject in South Africa nor is it any different in other countries, although it may be called integrated science instead of natural sciences, as in USA and Japan, or basic science, as in Nigeria. The subject curriculum is divided into four strands, namely 1) life and living, 2) matter and materials, 3) energy and change and 4) earth and beyond. The newly introduced curriculum (CAPS) specified when which strand is to be taught and that teachers must administer a school-based assessment task (SBAT) at the end of each strand. This assessment task needs to be standardised within the school and moderated before it is administered. Subject heads therefore have the huge task to ensure the quality of the assessment and the learners' responses after writing the task. This requires the $\mathrm{HoD}$, who both knows and teaches the subject, to be able to understand the challenges in the subject from both the learners and the teachers' perspective.

The HoD engages in certain practices to share the subject goals, develop a climate of high expectations and standards in the subject, monitor the instruction and assessment standards and model the desired teacher behaviours as well as promote school-based professional development. An account of these practices is given under the following subheadings. 


\section{Teaching of Natural Sciences}

Of the $30 \mathrm{HoDs}$ who responded to the questionnaire, $18(60 \%)$ actually taught natural sciences (Figure 2). These HoDs would likely understand the subject challenges, prove to have the needed subject expertise and be in a position to work with the teachers in the subject instead of working for them.

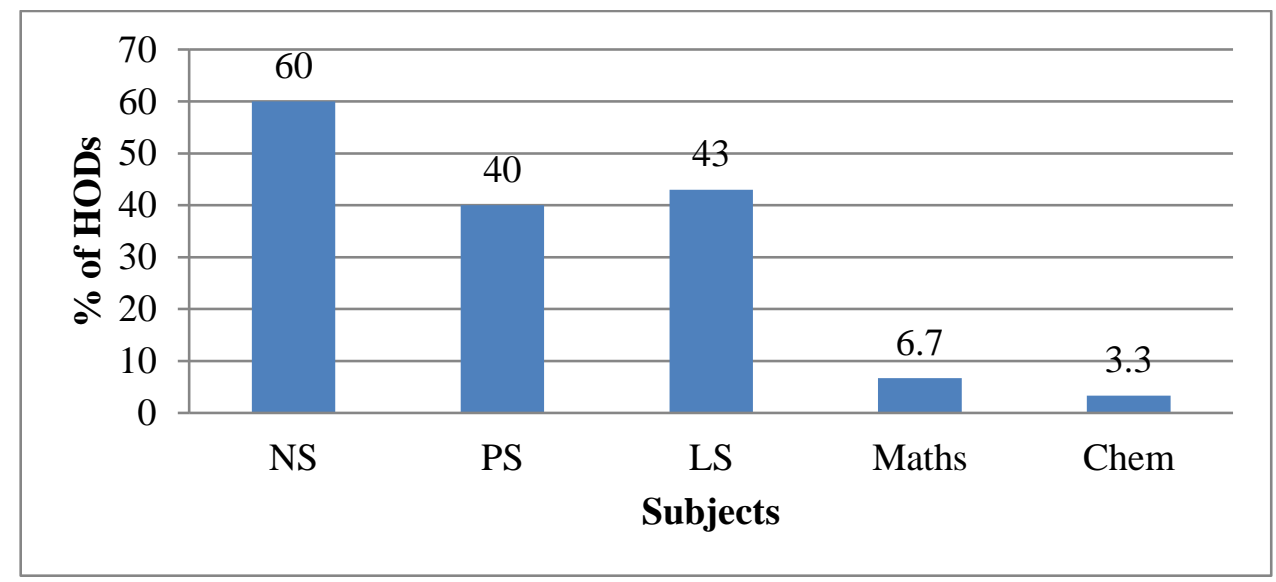

Figure 2: Subjects taught by the participating heads of department

The HoD respondents did not teach natural sciences only; they also taught either physical sciences or life sciences or mathematics. The number of HoD respondents who taught physical sciences $(12 ; 40 \%)$ was almost equal to the number of those who taught life sciences $(13 ; 43 \%)$.

\section{Qualifications/Specialisation of Heads of Department with Regards to Natural Sciences}

Because of the interdisciplinary nature of natural sciences, the HoD is expected to have the ability and knowledge to assist the teachers, who may not have expertise in other science disciplines. Figure 3 shows the specialisation of the $30 \mathrm{HoDs}$ that participated in this study.

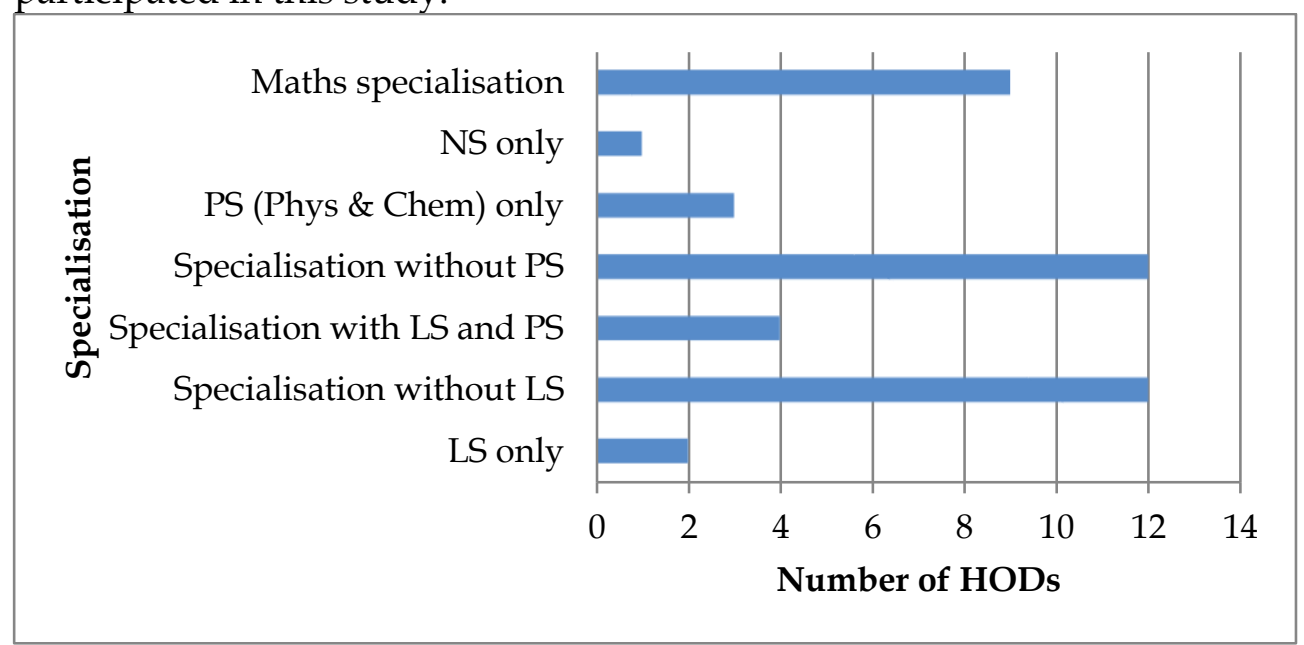

Figure 3: Subject specialisation of the participating heads of department

Figure 3 shows that almost half of the HoD respondents (12) had specialised in physical sciences or life sciences and almost a third (9) had specialised in 
mathematics. Those without life sciences specialisation may not be confident teaching $25 \%$ of the natural sciences syllabus, and those without physical sciences specialisation may not be confident teaching $50 \%$ of the syllabus. At the same time, HoDs themselves cannot be specialists in all five or six science disciplines. They are likely to support teachers only in the area of their expertise. HoDs that did not specialise in the sciences are likely to use other teachers in the school, such as senior teachers in the subject, to assist them with monitoring the said subject. This provides an opportunity for shared or distributed leadership, as advocated by Spillane et al. (2004). The teaching experience of the 112 teacher respondents is presented in Table 4.

Table 4: Teaching experience of the teacher respondents

\begin{tabular}{|l|c|c|c|c|c|}
\hline $\begin{array}{c}\text { Teaching } \\
\text { experience }\end{array}$ & $\begin{array}{c}\text { NS } \\
\text { Grade 8 }\end{array}$ & $\begin{array}{c}\text { NS } \\
\text { Grade 9 }\end{array}$ & $\begin{array}{c}\text { PS } \\
\text { Grade 10 }\end{array}$ & $\begin{array}{c}\text { PS } \\
\text { Grade 11 }\end{array}$ & $\begin{array}{c}\text { PS } \\
\text { Grade 12 }\end{array}$ \\
\hline 1-2 years & 17 & 13 & 12 & 11 & 4 \\
\hline 3-5 years & 18 & 17 & 12 & 7 & 5 \\
\hline 6-10 years & 20 & 18 & 4 & 4 & 4 \\
\hline$>$ 10 years & 14 & 18 & 10 & 6 & 3 \\
\hline $\begin{array}{l}\text { No } \\
\text { experience }\end{array}$ & 27 & 31 & 58 & 73 & 81 \\
\hline
\end{tabular}

Of the 112 teacher respondents in this study who taught natural sciences, at least 58 , or a little more than half $(52 \%)$, had not taught the physical sciences strand beyond Grade 9. Even more respondents had not taught Grades 11-12 (73 and 81, respectively). Perhaps these respondents did not have experience in teaching Grades 10-12 physical sciences and therefore may not be in a position to lay the proper physical sciences foundation for Grades 10-12.

These respondents are more likely to need classroom support in $50 \%$ of the natural sciences syllabus in order to teach it effectively and to the correct depth. They may be weary of doing experiments in science and to set the prescribed common assessment tasks on their own. They may need the HoD to assist them more closely for $50 \%$ of the time. This study did not focus on the earth and beyond strand of natural sciences. If these respondents are inexperienced in earth and beyond as well, then they will only be comfortable teaching $25 \%$ of the syllabus. The teacher respondents were asked to indicate their HoD's subject expertise (Figure 4). 


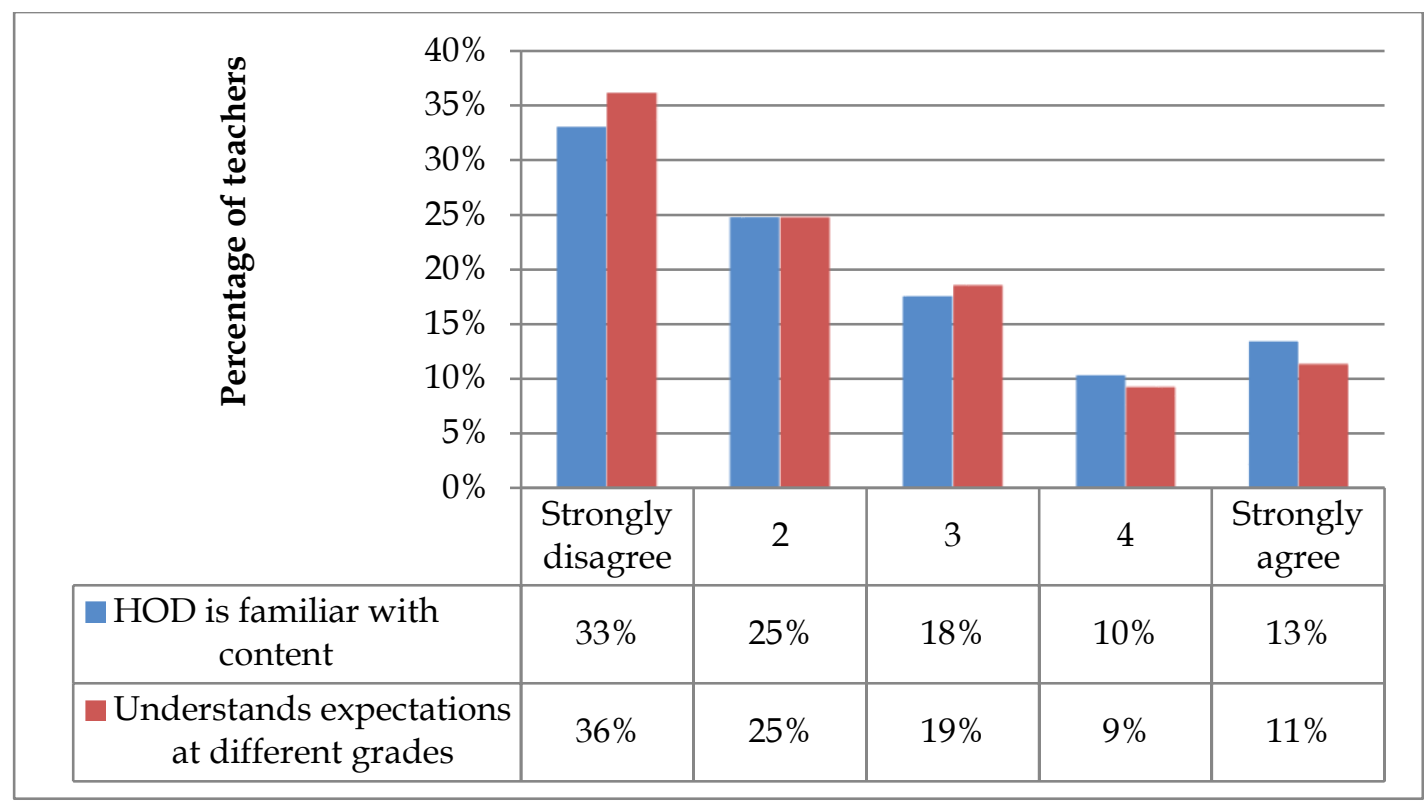

Figure 4: Teacher respondents' rating of their head of department's subject expertise

Figure 4 shows that $58 \%$ of the teacher respondents disagreed that their HoDs were familiar with the subject content, and $61 \%$ believed that their HoDs did not understand the subject expectations at different grades. Familiarity with subject content means that the HoD knows how deep and wide the teachers should present the subject. This involves understanding the subject progression, sequencing and the coherence of topics so that the building blocks and anchors for the subject are formed. Teachers expect the HoD to know areas that are problematic and to also prepare and caution teachers, accordingly, giving them tips and transferring the necessary skills on how to tackle those problematic sections. With the new curriculum, there are assessment standards, expectations and demands that need to be met for natural sciences.

Natural sciences has a practical component, and the new curriculum specifies that all leaners must do a common assessment task, which is based on the practical task. Practical work demands that the teacher prepares the experiment/investigation, ensures that the equipment is available and in working condition and understands the experiment and what could go wrong in order to assist the learners. The development, design, and moderation of the task as well as the scheduling of the time and space for doing the common assessment tasks by all learners in the grade on the same day requires the HoD's coordination. Once the task has been marked, the HoD can use the scores to analyse the level of understanding of the particular concept by learners and identify areas of support for groups of learners.

About a quarter of the teacher respondents (23\%) agreed that their HoDs were familiar with the natural sciences content (Figure 4), while $20 \%$ agreed that their HoDs understood the subject expectations at different grades. Figure 2 showed that almost two thirds of the HoD respondents were teaching natural sciences. This means that more than a third were not teaching the subject that they were leading. The fact that they did not teach the subject contributes to their lack of 
understanding of the expectations of subjects per grade and their non-familiarity with the subject content, a matter confirmed by the teacher respondents.

\section{How Heads of Department Spend Their Time}

The HoD respondents were asked how much time they spend on some leadership practices (Figure 5). On average, less than a quarter of them agreed to providing any form of professional development to the teachers. Over half of the HoD respondents $(60 \%)$ in the study disagreed to practising any form of professional development activities. Fifty-five percent (55\%) of the participating HoDs did not provide opportunities to learn and $60 \%$ both did not coordinate professional development and take responsibility for teachers to do well. In addition, 51\% did not take responsibility for improving instruction and 53\% did not provide classroom observation feedback. Predominantly, more than half of the HoD respondents in this study did not coordinate professional development $(60 \%)$ or take responsibility for improving instruction (60\%) or for teachers to do well. Only a quarter of the respondents $(25 \%)$ agreed to providing opportunities for teachers to learn and taking responsibility to improve instruction (25\%) (Figure 5).

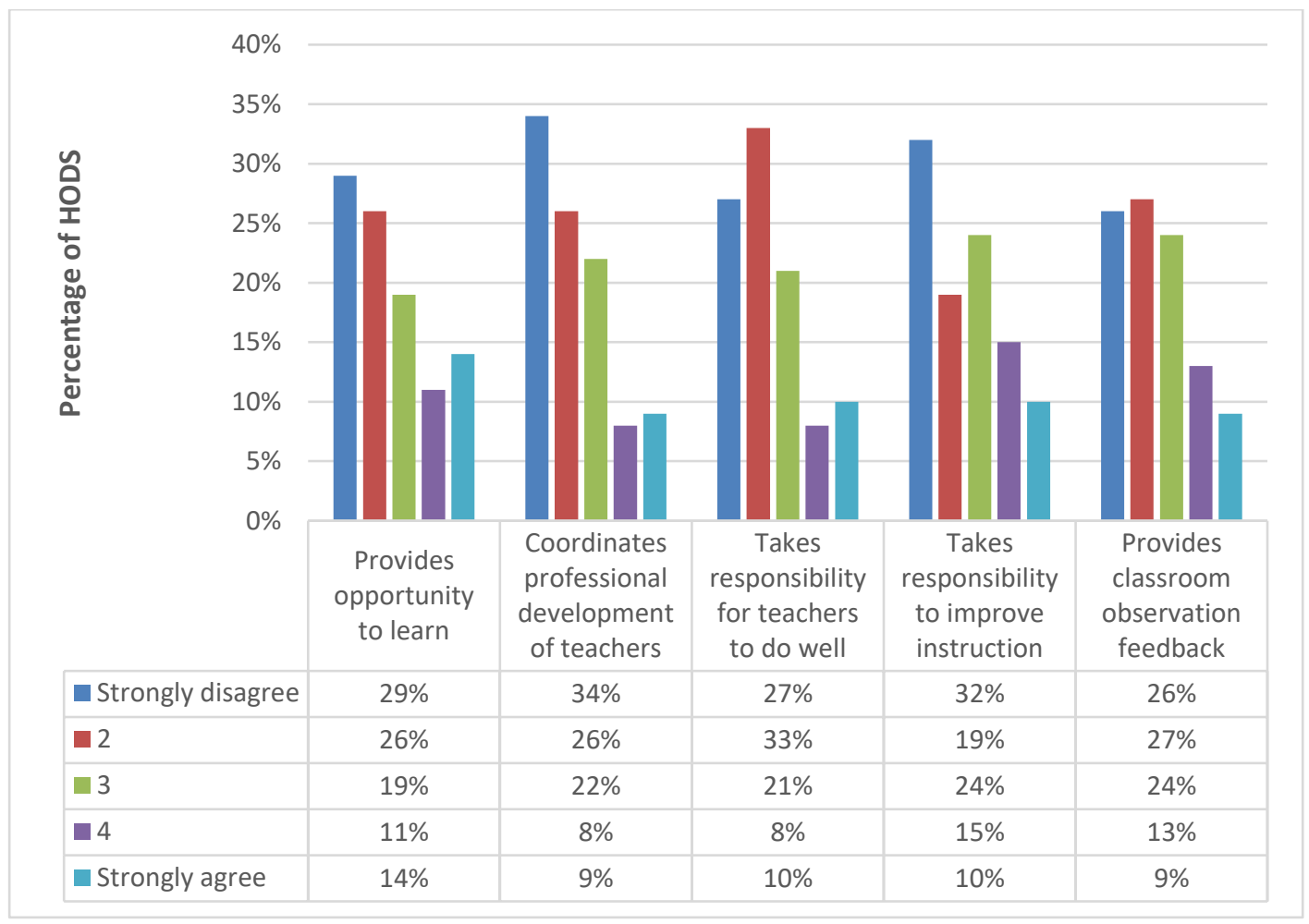

Figure 5: How participating heads of department spend their time

HoD respondents were also asked how much time they spend doing administrative work (Figure 6). It was found that they spend most of their time doing administrative work. Almost three quarters $(72 \%)$ of the HoD respondents indicated that they spend most of their time doing internal administration at the school. In addition, almost two thirds (62\%) indicated spending time on paperwork, two thirds $(66 \%)$ indicated spending their time responding to e-mail or fax correspondences, while three quarters $(75 \%)$ of the respondents indicated 
spending most of their time managing late coming at the school and $62 \%$ indicated spending their time responding to local district office demands.

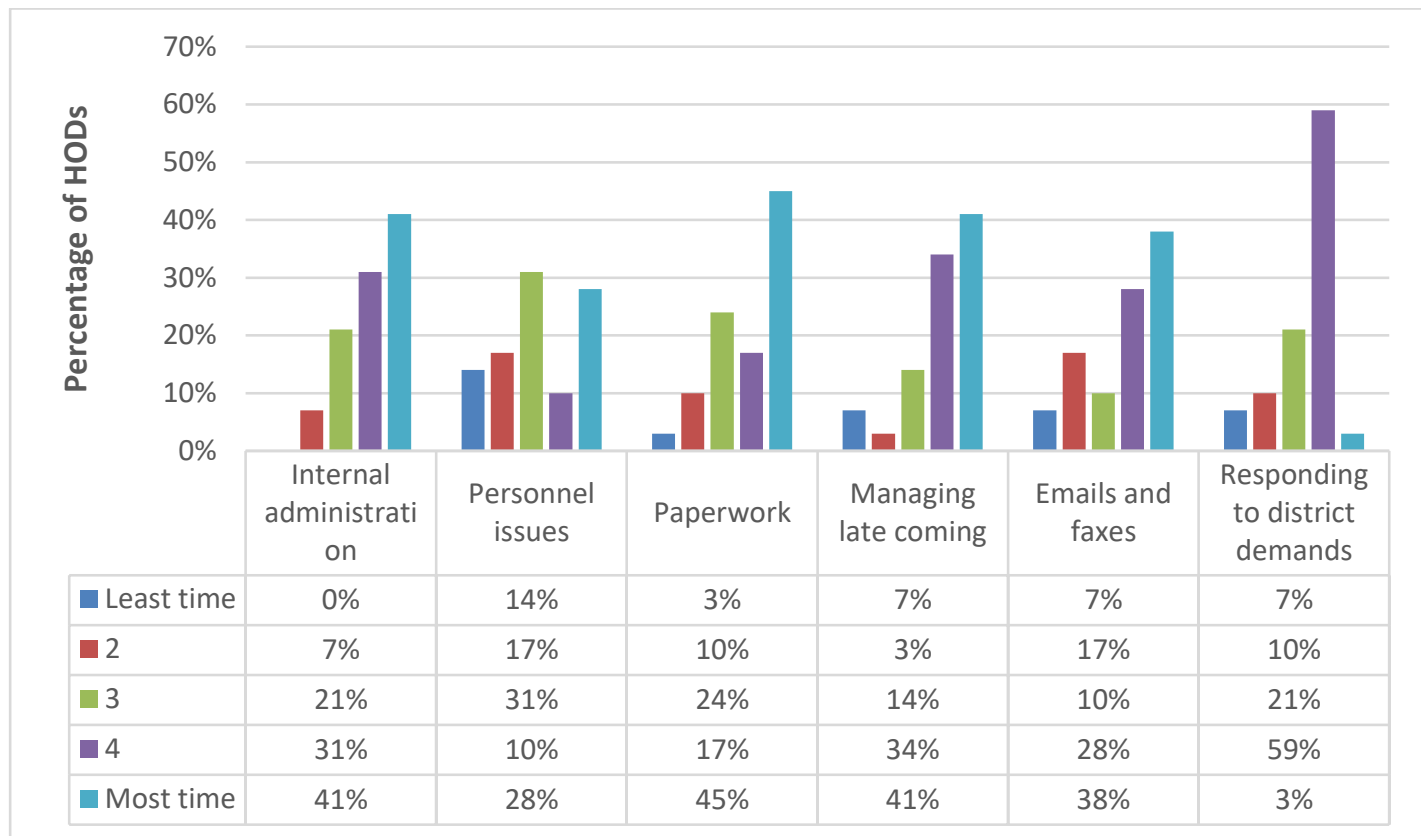

Figure 6: Time spent on administrative work by heads of department

\section{Curriculum Management}

HoD respondents were asked to indicate whether they spend time on different aspects related to curriculum management (Figure 7). $72 \%$ of participating HoDs indicated that they spend almost all their time preparing lesson and teaching. An equal number of participating HoDs (52\%) spend their least time in training teachers or providing instructional leadership while $48 \%$ spent the least time of given demo lesson to teachers

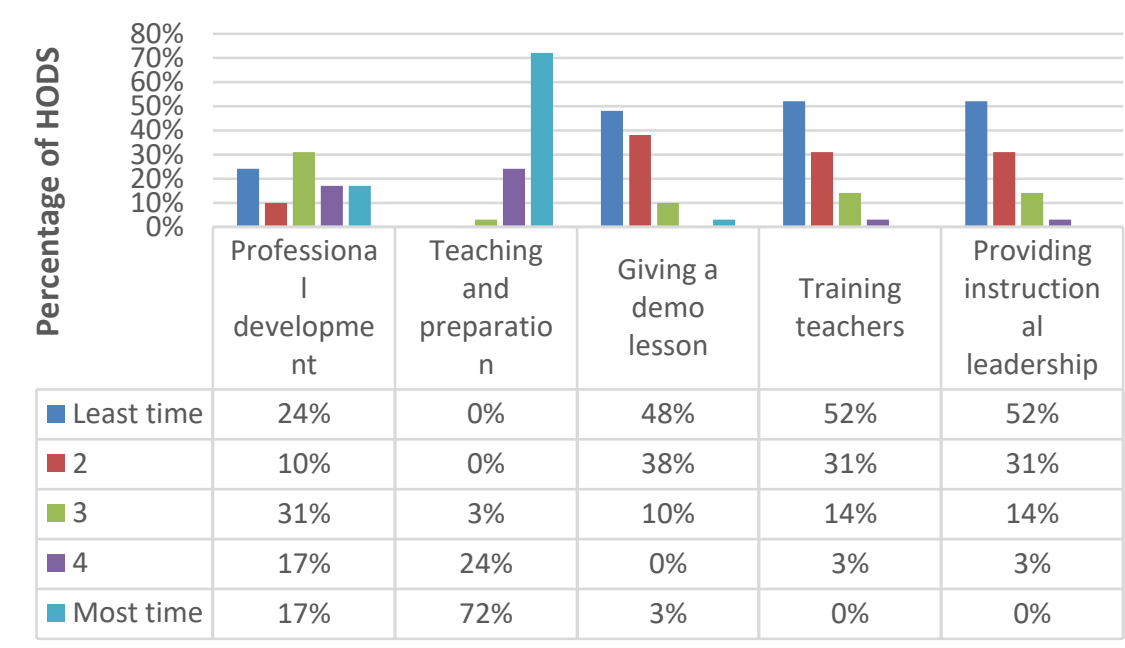

Figure 7: Time spent on curriculum management by participating heads of department 
Teacher respondents were also asked to indicate the frequency with which HoDs engaged in curriculum management activities (Figure 8).

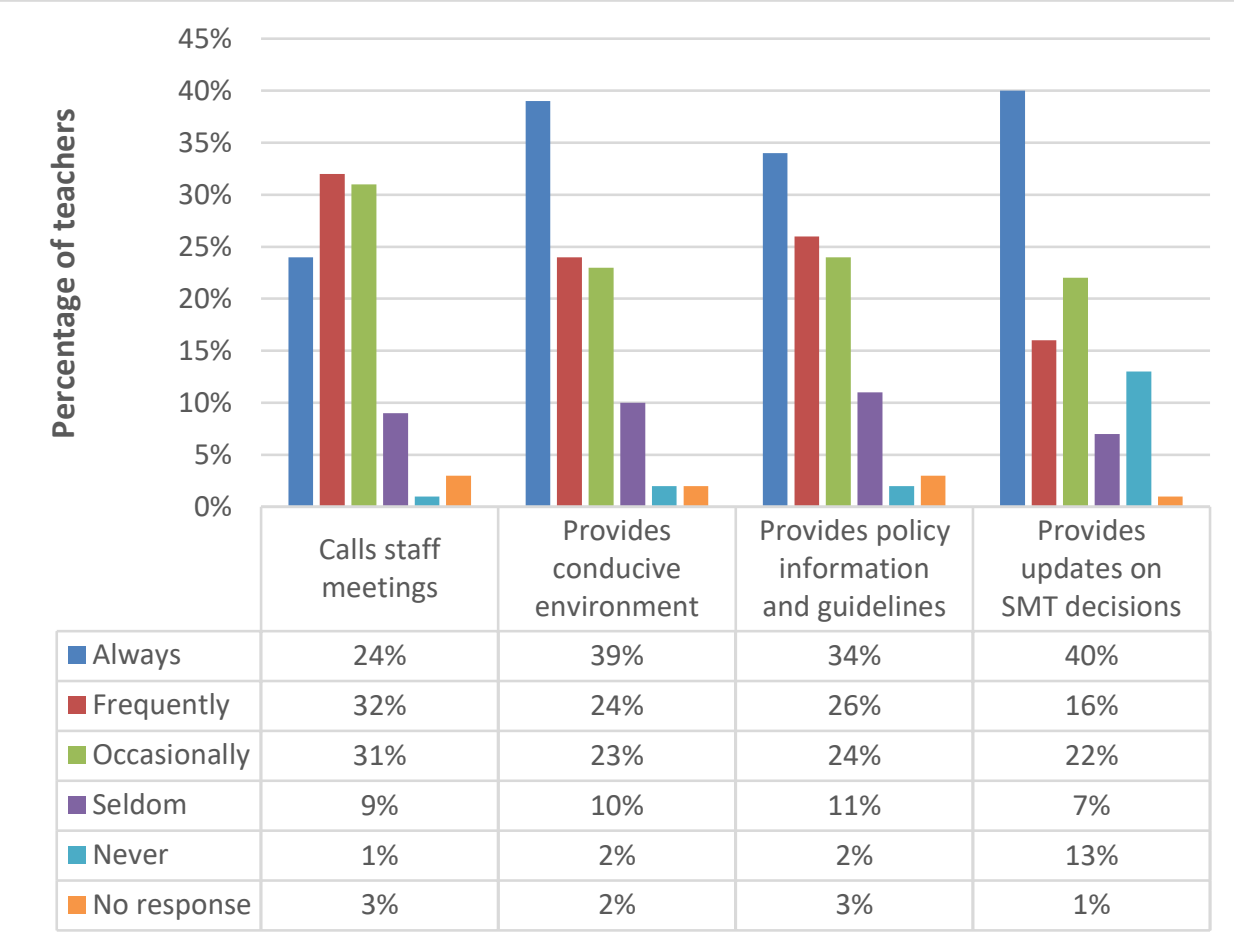

Figure 8: Time spent by heads of department on curriculum management according to teacher respondents

More than half of the teacher respondents (56\%) indicated that their HoDs called subject staff meetings and provided feedback on SMT decisions more frequently. Almost two thirds of the respondents (63\%) indicated that the HoDs frequently provided a conducive environment for instruction, whereas $60 \%$ indicated that time was spent providing policy information and guidelines. Again, more than half $(56 \%)$ of the teacher respondents agreed that HoDs provide updates on SMT decisions.

The teacher respondents indicated that HoDs performed curriculum management. Curriculum management in this context relates to all the activities that involve compliance to the demands of the SMT, district and provincial office for a particular subject offering. Most schools expect HoDs to have subject meetings. Fifty-six percent $(56 \%)$ of the participating HoDs did this frequently, although the meaning of frequently may vary from school to school. The content of what is addressed at the subject meetings also varies from school to school. HoDs are also responsible for ensuring that all teaching and learning resources and teaching spaces, such as adequately equipped laboratories, are available and conducive.

\section{The Most Helpful Person}

The participating teachers were asked to indicate which person they found most helpful regarding instructional matters (Figure 9). Across broad, 35.1\% of the 
responding teachers indicated that the HoD was most helpful, while $37.7 \%$ indicated that the senior teacher was most helpful leaving out $27.2 \%$ of the responding teachers indicating that the subject advisor was most helpful.

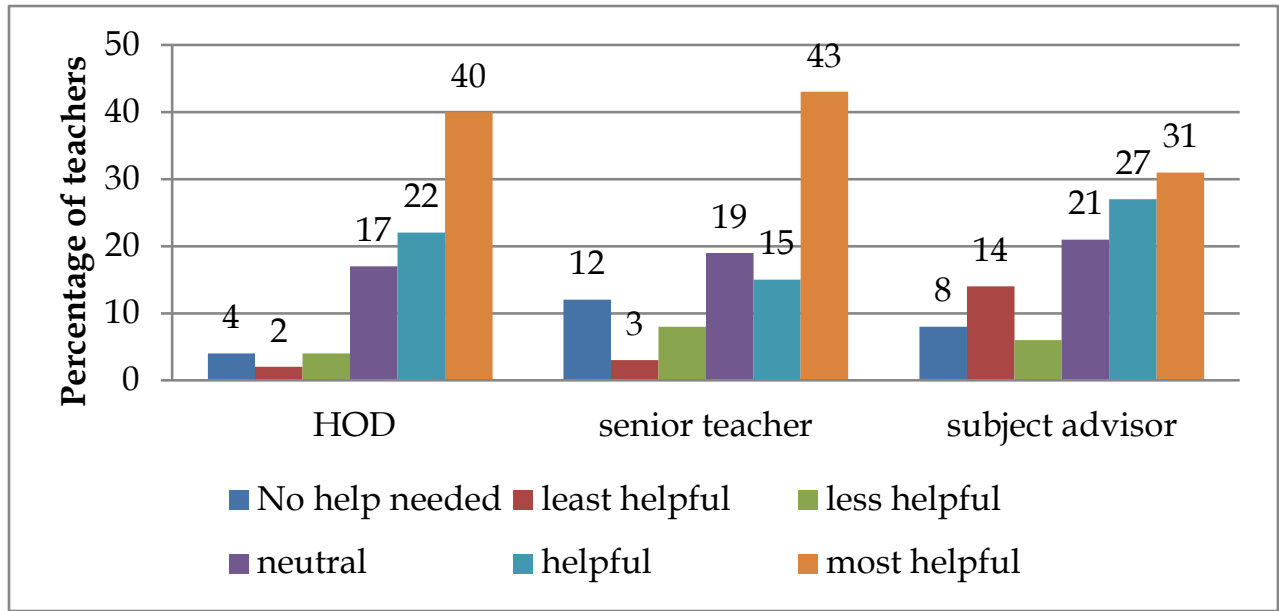

Figure 9: Teacher respondents' perspectives on the most helpful person

\section{Instructional Leadership and In-Classroom Support}

The HoD's key role, other than teaching, is providing instructional leadership. Inclassroom support is one of the ways in which the HoD provides leadership. The capacity of HoDs to provide in-classroom support and leadership in general was explored. This section discusses how the participating teachers and responded to the questions regarding instructional leadership. Figure 10 illustrates how teacher respondents rated the frequency with which HoDs monitored standards.

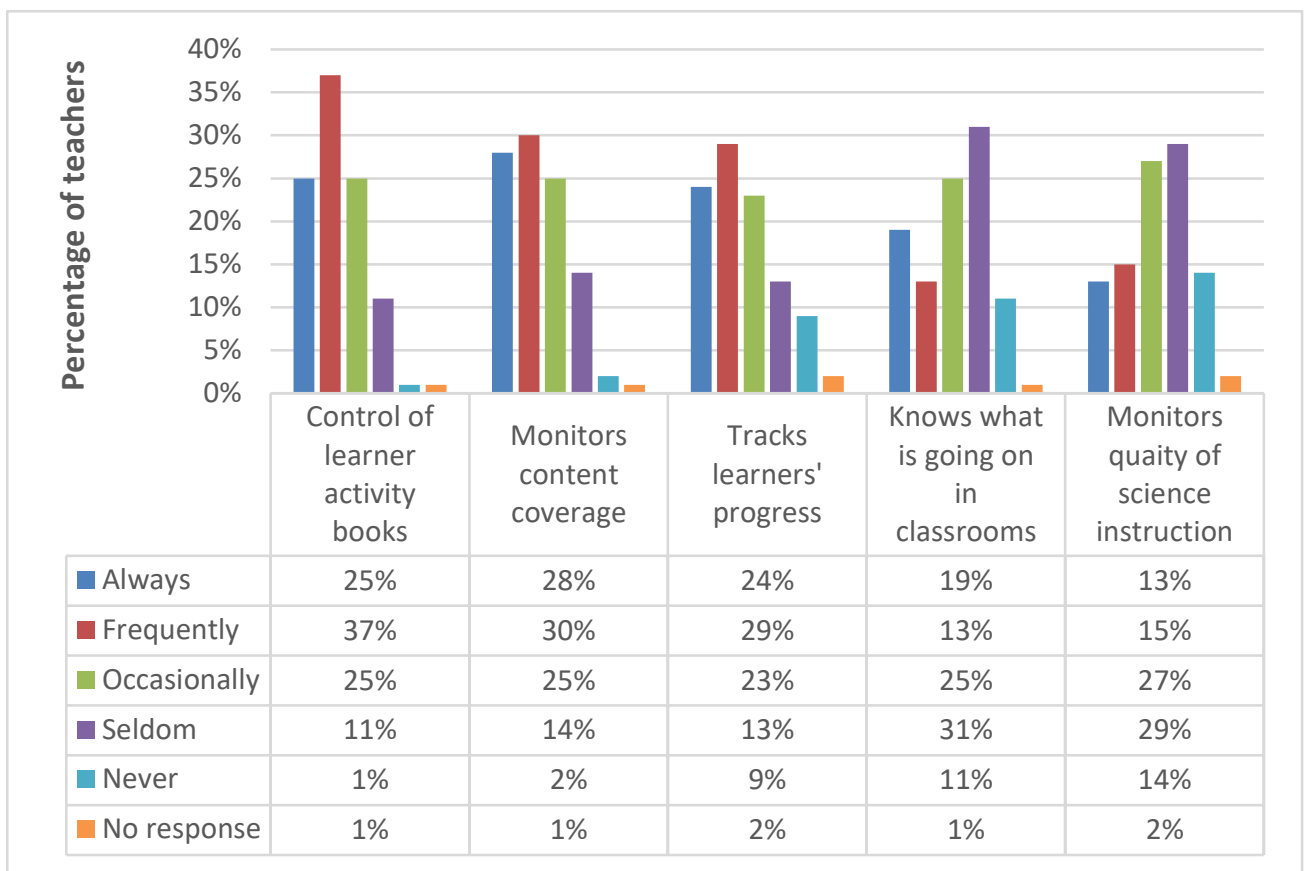

Figure 10: Frequency of monitoring standards by heads of department according to teacher respondents 
Regarding activities that HoDs did to monitor instructional activities, $62 \%$ of the teacher respondents indicated that their $\mathrm{HoD}$ more often than not controlled the learners' activity books, and 58\% agreed that HoDs monitored the subject content coverage. Over half of the respondents (53\%) indicated that their HoD frequently tracked learners' progress. Thirty-one percent $(31 \%)$ indicated that the HoD seldom (31\%) or occasionally (25\%) made time to understand what was going on in the science classrooms. Fifty-six (56\%) of the respondents indicated that the HoD occasionally or seldom monitored the quality of the science instruction.

Furthermore, teacher respondents were asked how frequently they interacted with the HoD regarding instruction and in-classroom support (Figure 11).

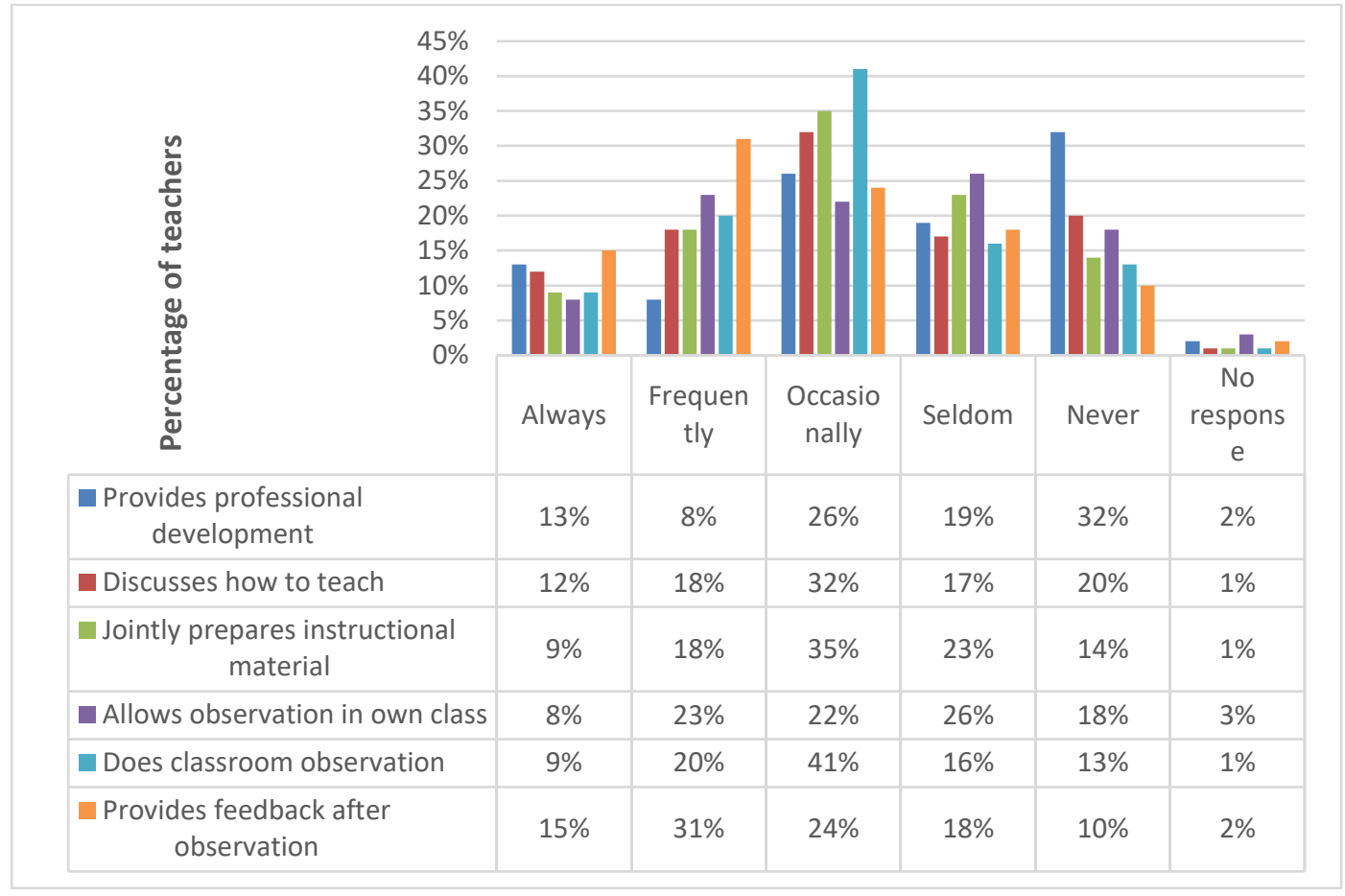

Figure 11: Frequency of instructional leadership activities by heads of department according to teacher respondents

Forty-one percent $(41 \%)$ of the teacher respondents indicated that their HoD occasionally did classroom observations. Over a third $(35 \%)$ indicated that the $\mathrm{HoD}$ occasionally developed instructional material jointly, and $32 \%$ that they occasionally discussed how to teach natural sciences. Almost half of the respondents $(46 \%)$ indicated that they frequently or always received feedback from the HoD after classroom observations. About a third (32\%) indicated that their HoD never provided professional development, while almost half $(44 \%)$ indicated that the HoD seldom or never allowed teachers in their classroom for observations or demonstrative lessons.

\section{Subject Meetings}

Subject meetings are formal organisational routines and are one of the aspects of organisational infrastructure that can enable or constrain leadership practice. HoDs use these routines as monitoring tools to see if various components of the 
department are working as intended. Both teachers and HoD respondents were asked about the content of the subject or departmental meetings. Table 5 shows the responses of both the HoD and teacher respondents.

Table 5: Items discussed at departmental meeting

\begin{tabular}{|l|l|l|l|l|l|}
\hline \multirow{2}{*}{ S/N } & \multicolumn{1}{|c|}{ Agenda items at meetings } & \multicolumn{2}{c|}{ HoDs } & \multicolumn{3}{c|}{ Teachers } \\
\cline { 3 - 6 } & Mean & Rank & Mean & Rank \\
\hline 1 & Question-paper monitoring & 4.6 & 1 & 4.09 & 1 \\
\hline 2 & $\begin{array}{l}\text { Account of the term's work or content } \\
\text { coverage }\end{array}$ & 4.4 & 3 & 3.82 & 2 \\
\hline 3 & Learner-assessment issues & 4.5 & 2 & 3.73 & 4 \\
\hline 4 & $\begin{array}{l}\text { Analysis of learner scores to inform } \\
\text { instruction }\end{array}$ & 3.5 & 12 & 3.71 & 4 \\
\hline 5 & Curriculum and learner outcomes & 4.2 & 4 & 3.71 & 4 \\
\hline 6 & Start and end-of-term issues & 4.2 & 5 & 3.61 & 6 \\
\hline 7 & Plan of next remedial or enrichment steps & 4.0 & 6 & 3.61 & 6 \\
\hline 8 & Clarification of the department's direction & 3.8 & 11 & 3.5 & 8 \\
\hline 9 & Textbook and course material & 3.97 & 7 & 3.5 & 8 \\
\hline 10 & Development and sharing of lesson plans & 2.67 & 15 & 3.42 & 10 \\
\hline 11 & Distribution of leadership activities & 3.93 & 8 & 3.38 & 11 \\
\hline 12 & School improvement plan & 3.9 & 9 & 3.37 & 12 \\
\hline 13 & Instructional evaluation & 3.83 & 10 & 3.33 & 13 \\
\hline 14 & Professional development & 2.83 & 14 & 3.32 & 14 \\
\hline 15 & Policy reviews & 3.27 & 13 & 2.94 & 15 \\
\hline 16 & Budget & 2.6 & 16 & 2.23 & 16 \\
\hline
\end{tabular}

Both HoD and teacher respondents indicated that they discussed question-paper monitoring more than any other item, as this was ranked as the top item in the frequency of subject or departmental meeting agenda items. Instructional assessment included setting, moderation and administration of tests, examination question papers and school-based assessment tasks. The teacher respondents ranked account of the term's work as the next most frequent agenda item discussed, whereas the HoD respondents, on the other hand, identified learnerassessment issues as the next item most discussed and account of the term's work third. The teacher respondents ranked "development of lesson plans" tenth, while HoD respondents ranked it fifteenth among the items discussed. Professional development, instructional evaluation, and policy reviews were among the agenda items that were least discussed. Respondents from both groups corroborated that budget was the item least discussed in subject or departmental meetings.

\section{Discussion}

The capacity of the HoD respondents in this study to lead instruction was limited in many ways. First, they could not differentiate between curriculum management and instructional leadership. For most of them, they could tick the checklist in terms of management issues such as monitoring curriculum coverage from learner-books, calling subject or departmental meetings, counting the number of assessment tasks given etc. Only a few, however, were able to influence 
the quality of what was happening in the classroom. Curriculum management does not require the HoD to visibly interact with the teachers on a personal level. Instructional leadership, on the other hand, involves constant interaction and professional dialogue in the form of one-on-one face-to-face meetings, or group meetings, classroom observation and feedback, lesson demonstrations of best practices, and leading by example. This is the actual sphere and means of influence and this is how leadership works.

Any HoD can call the meeting and tick that output from the checklist; however, what is discussed at the meetings determines the difference between management and leadership. Schools have routines such that on certain days all learner-books are submitted to the HoD for moderation. If the $\mathrm{HoD}$ signed and stamped the learner-books, it can be ticked from the management checklist. However, an instructional leader will look at the content of the learners' activity books and the quality of the science writing to pick up areas for development. In addition, they will create interventions in the classroom or work with the teacher(s) concerned depending on the trend that is picked up. In this study, $62 \%$ of teacher respondents indicated that their HoD frequently monitored the learners' activity books, but that they occasionally or seldom monitored the quality of instruction.

These managerial duties are what Peacock (2013) referred to as simply clerical tasks that detract the HoDs from their instructional duties. They are often listed as official HoD responsibilities but are not instructional leadership activities. This situation also causes HoDs to suffer a similar fate experienced by principals. As Ndoziya (2014) reported that principals spend most of their time on administrative functions and disciplinary issues. Peacock (2013) identified these managerial processes as those that support instruction, such as budgeting, scheduling/routines, and recruitment of teachers. Spillane and Hopkins (2013) also suggested that organisational infrastructures, which include routines, processes, and structures, are important for instructional delivery.

More than half of the teacher respondents (58\%) indicated that they occasionally or seldom spend time preparing instructional material as a group (Figure 11). Helterbran (2008) asserted that collaborative planning assists teachers to reflect carefully on what works, and what does not, in a particular school context and within a group of learners. These teachers can then work together to address challenges in the curriculum and with their teaching choices. The HoD respondents in the study missed the opportunity to develop, facilitate, monitor, and support common instructional material, such as lesson plans and assessment tasks. HoDs do not have to develop this on their own but can do it jointly with teachers as this offers an opportunity to distribute leadership and develop the teachers professionally. Most teachers prepare their own materials, which can be appreciated, but the quality of the materials may be compromised.

Second, just over half of the HoD respondents (57\%) taught natural sciences in either Grades 8 or 9 . This means that more than a third $(43 \%)$ did not teach the subject and would therefore find it difficult to know what goes on in natural sciences classrooms ( $42 \%$ seldom or never know what is going on). They would 
therefore not be able to monitor the quality of natural sciences instruction (43\% seldom or never). More than half of the teacher respondents $(58 \%$ and $61 \%$ respectively) agreed that their HoDs were neither familiar with the content nor understood the subject expectations at the different grades. HoDs that do not teach the subject would normally pay more attention to the subjects that they teach and very little to natural sciences.

If $45 \%$ of the teacher respondents indicated occasional classroom visits by HoDs, how likely is it that the HoDs know what goes on in the classroom or where instructional practice is enacted and actualised? How can HODs possibly ascertain the quality of instruction at a distance, apart from the products of instruction evident in learner books and learner progress reports? How do HoDs know where to intervene and support teachers in the classroom? They will not be in a position to know first-hand what learners are struggling with and how to approach such challenges and will not be able to share it with the other teachers in the grade. Therefore, their capacity to provide instructional leadership is challenged. The minimum that they could do is to resort to curriculum management, which can be achieved through paperwork and does not involve physical presence of visible leadership in the subject (Southworth, 2002). Almost half of the teacher respondents $(46 \%)$ agreed that their HoDs provided feedback after observation (Aubrey-Hopkins \& James, 2002). Providing feedback encourages the teachers to look back at their own instructional practice. The HoD uses this opportunity to identify areas on professional development and identify any other intervention in the classroom or even in the whole grade or school. In addition, half of the teacher respondents $(49 \%)$ indicated that their HoDs occasionally or seldom allowed teachers in their classrooms to demonstrate best practice (Benedict, 2009). These HoDs failed to position themselves as models of best professional and instructional practices. This is partly because they do not teach natural sciences and it would thus be difficult to go out of their way to plan and prepare a subject that they do not teach

Third, the subject specialisations of the HoD respondents could contribute to their capacity of providing effective instructional leadership. Subject specialisation provides the HoD with professional credibility as a specialist in a particular subject (Stein \& Nelson, 2003). It boosts the professional esteem and confidence of the HoD as they professionally interact and engage with the teachers that they are leading. In this study, few of the HoD respondents $(15 \%)$ had a qualification that enabled them to teach all subject strands of natural sciences. Half of the HOD respondents were only specialised enough to teach $50 \%$ of the strands (physical sciences - physics and chemistry specialisation) and another $46 \%$ were specialised to teach only $25 \%$ of the strands (life sciences - zoology and botany specialisation). This affects the HoD's capacity to provide effective instructional leadership in the whole subject and all the subject strands. More than half of the teacher respondents $(78.5 \%)$ did not have physical sciences teaching experience, which would have enabled them to teach $50 \%$ of the syllabus. This implies that they would have needed plenty of support in teaching those strands. These teachers are likely to rely on the senior teacher or the HoD in order to teach these strands effectively and confidently. This reliance might have resulted in the teacher 
respondents rating senior teachers in the subject as being the most helpful person $(37.7 \%)$.

A senior teacher is a specialist in the subject who may not be formally appointed to a particular position in the school and most of the time would lead the subject under the supervision of the HoD. The presence of senior teachers allows distributed leadership to be enacted where necessary. In some schools, the HoD allocates the subjects to the senior teachers, and in some cases, the teachers' own agency (Sherer, 2008) and professional credibility (Stein \& Nelson, 2003) lead them to practice as a senior teacher. The challenge of departments being a group of subjects could be addressed by recognising senior teachers and allocating them to provide instructional leadership in order to achieve learner outcomes.

The last HoD-capacity challenge is the availability of time in order to provide the much-needed instructional leadership. Most of the HoD respondents' time is spent on teaching and doing administrative work. Administrative duties outweigh curriculum management and instructional leadership (Collier et al., 2002). HoDs are challenged by the urgency to balance the competing responsibilities of managing the department, teaching, and enacting instructional leadership (Feeney, 2009; Zepeda \& Kruskamp, 2007) without receiving any release time for these responsibilities. They often have to find time outside working hours to fulfil some of the responsibilities. 96\% of HoD respondents indicated that they spend most of their time teaching and have no time to help other teachers teach better or to observe what they do in class in order to support them whereas only $85 \%$ of their time as stipulated by the department should be spent on teaching and preparing to teach.

HoD respondents seemed to know what was expected of them, even if they did not practise it. The views of the teacher respondents in terms of what the HoDs say they do seem to differ. This is evident in the subject meeting agenda items; there was no alignment in terms of the frequency of what is discussed. These capacity challenges are not necessarily unique to HoD research or to South Africa, but they can be seen in other countries that are yet to adopt the distributive leadership style.

\section{Conclusion}

Natural sciences HoDs had either a physical sciences qualification or an life sciences specialisation. When the HoD possesses a physical sciences qualification, this implies that their expertise lies in $50 \%$ of the natural sciences syllabus, whereas the HOD with a life sciences specialisation may only be comfortable with $25 \%$ of the syllabus. This affects the support that the HoD can provide to the teachers. The survey also showed that teachers may not know the subject demands and expectations beyond Grade 9 and may not know the challenges in physical sciences that learners might have. If the HoDs themselves have capacity challenges and cannot leverage the senior teacher opportunity, the quality of instruction may be compromised. The participating HoDs in this study were therefore only doing their curriculum managerial duties instead of providing instructional leadership. The specialisation shortcomings might have led to a lack 
of subject teacher professional development and a lack of willingness to model best practice in terms of demo lessons and common planning. The majority of the HoD respondents had qualifications that limit their ability to support and develop teachers within natural sciences.

What is unique about these findings is the subject-specific demands of natural sciences and how schools have adapted their systems to accommodate a complex subject such as natural sciences in their own contexts. The HoD's capacity is compromised because they do not teach the subject and therefore do not know what is going on in natural sciences classrooms. HoDs rarely coordinate or provide professional development or even discuss it at meetings, which compromises their interaction with the teachers and them being seen as professional leaders in the subject. In addition, HoD capacity is highly affected by the lack of release time, because most of the HoD respondents indicated that they spend most of their time teaching and doing administrative work.

\section{Recommendations}

We recommend that HoDs receive more focused subject-specific training in the natural sciences subdisciplines, especially the physical sciences strand. It is envisaged that HoD capacity can further be improved by allocating release time from teaching duties in order to attend to some instructional leadership activities. Where schools still have the opportunity to appoint science HoDs, it is recommended that they consider an $\mathrm{HoD}$ for junior secondary science that is separate from the senior secondary science. This is so that senior secondary issues and urgency to provide matric results do not overshadow junior secondary issues. Furthermore, we recommend the need to re-examine the structures and functions within science departments to enhance the potential for much stronger instructional leadership by the appointed HoDs. Since HoD positions cannot be reversed, it is recommended that appointing senior/lead/master teachers be encouraged to address the instructional leadership deficit, especially for natural sciences teachers.

\section{Limitations}

In this paper, we only reported on the survey data that were collected in 77 schools as part of a bigger study on the instructional leadership of middle management. We did not report on the follow-up interviews and observational data that were collected from the schools.

\section{References}

Angelle, P. S., \& DeHart, C. A. (2011). Teacher perceptions of teacher leadership: Examining differences by experience, degree, and position. NASSP Bulletin, 95(2), 141-160. https:/ / doi.org/10.1177/0192636511415397

Aubrey-Hopkins, J., \& James, C. (2002). Improving practice in subject departments: The experience of secondary school subject leaders in Wales. School Leadership $\mathcal{E}$ Management, 22(3), 305-320. https:/ / doi.org/10.1080/1363243022000020426

Benedict, M. R. (2009). Teacher leaders building social capital in secondary departments: Three case studies. [Doctoral dissertation]. University of Wisconsin.

Bolam, R., \& Turner, C. (2003). Heads of secondary school subject departments and the improvement of teaching and learning. In M. Wallace and L. Poulson (eds.). Learning to 
read critically in educational leadership and management. Sage Publications Limited. http://dx.doi.org/10.4135/9781446216576.n6

Brown, M., Rutherford, D., \& Boyle, B. (2000). Leadership for school improvement: The role of the head of department in UK secondary schools. School effectiveness and school improvement. 11(2), 237-258. https://doi.org/10.1076/09243453(200006)11:2;1-Q;FT237

Bush, T., Joubert, R., Kiggundu, E., \& Rooyen, J. V. (2010). Managing teaching and learning in South African schools. International Journal of Educational Development, 30(2), 162-168. http://dx.doi.org/10.1016/j.ijedudev.2009.04.008

Busher, H., Harris, A., \& Wise, C. (2000). Subject leadership and school improvement. Paul Chapman/Sage.

https://www.researchgate.net/publication/282809119_Busher_H_Harris_A_an d_Wise_C_2000_Subject_leadership_and_School_Improvement_London_Paul_C hapman

Chambalala, G., \& Naidoo, P. (2021). Teachers' and middle managers' experiences of principals' instructional leadership towards improving curriculum delivery in schools. South African Journal of Childhood Education, 11(1), 1-10. https://doi.org/10.4102/sajce.v11i1.910

Collier, J., Dinham, S., Brennan, K., Deece, A., \& Mulford, D. (2002). Perceptions and reality of the work of the secondary head of department. Leadership in Schools, $30(2)$,

$17-26$.

https://eds.p.ebscohost.com/eds/pdfviewer/pdfviewer?vid=0\&sid=3cc0509693f3-4966-89d2-6a942fb4b088\%40redis

Department of Education (1999). Personnel administrative measures. Government Printers.

Feeney, E. J. (2009). Taking a look at a school's leadership capacity: The role and function of high school department chairs. The Clearing House: A Journal of Educational Strategies, Issues and Ideas, 82(5), 212-219. https:/ / doi.org/10.3200/TCHS.82.5.212219

Ghamrawi, N. (2010). No teacher left behind: Subject leadership that promotes teacher leadership. Educational Management Administration \& Leadership, 38(3), 304-320. https:// doi.org/10.1177\%2F1741143209359713

Glickman, C. D., Gordon, S. P., \& Ross-Gordon, J. M. (2018). Supervision and instructional leadership: A developmental approach (10th ed.). Pearson.

Hallinger, P. (2005). Instructional leadership and the school principal: A passing fancy that refuses to fade away. Leadership and Policy in School, 4(3), 221-239. https://doi.org/10.1080/15700760500244793

Hallinger, P., \& Murphy, J. (1985). Assessing the instructional management behaviour of principals. Elementary School Journal, 86(2), 217-247.

Harris, A., Busher, H., \& Wise, C. (2001). Effective training for subject leaders. Journal of In-Service Education, 27(1), 83-94. https://doi.org/10.1080/13674580100200139

Helterbran, V. (2008). Planning for instruction: Benefits and obstacles of collaboration. The International Journal of Learning, 15(1), 89-93. https://doi.org/10.18848/14479494/CGP/v15i01/45573

Highfield, C. (2010). Disparity in student achievement within and across secondary schools: An analysis of department results in English, mathematics and science in New Zealand. School Leadership and Management, 30(2), 171-190. https://doi.org/10.1080/13632431003685860

Kabeta, R. M., Manchishi, P. C., \& Akakandelwa, A. (2015). Instructional leadership and its effect on the teaching and learning process: The case of head teachers in selected basic schools in the central province of Zambia. International Journal of Science and Research, 4(4), 1876-1884. 
https://www.researchgate.net/profile/Rachel-Kabeta-

2/publication/339054797

Klar, H. W. (2012). Fostering department chair instructional leadership capacity: Laying the groundwork for distributed instructional leadership. International Journal of Leadership in Education: Theory and Practice, 15(2), 175-197. https://doi.org/10.1080/13603124.2011.577910

Lai, E., \& Cheung, D. (2013). Implementing a new senior secondary curriculum in Hong Kong: Instructional leadership practices and qualities of school principals. School Leadership and Management, 33(4), 322-353. https:// doi.org/10.1080/13632434.2013.813459

Lashway, L. (2002). Developing instructional leaders. ERIC Digest. https://www.gpo.gov/fdsys/pkg/ERIC-ED466023/pdf/ERIC-ED466023.pdf

McMillan, J. H., \& Schumacher, S. (2010). Research in education. Evidence-based inquiry. Pearson.

Melville, W., Wallace, J., \& Bartley, A. (2007). Individuals and leadership in an Australian secondary science department: A qualitative study. Journal of Science Education and Technology, 16(6), 463-472. https:/ / doi.org/10.1007/s10956-007-9081-3

Munje, P. N., Tsakeni, M., \& Jita, L. C. (2020). School heads of departments' roles in advancing science and mathematics through the distributed leadership framework. International Journal of Learning, Teaching and Educational Research, 19(9), 39-57. https:// doi.org/10.26803/ijlter.19.9.3

Naicker, I., Chikoko, V., \& Mthiyane, S. E. (2013). Instructional leadership practices in challenging school contexts. Education as Change, 17(S1), S137-S150. https:// doi.org/10.1080/16823206.2014.865999

Ndoziya, C. (2014). The instructional leadership roles of the secondary school principals towards quality school improvement in Zimbabwean schools [Doctoral thesis, University of South Africa]. University of South Africa Research Repository. http://hdl.handle.net/10500/19992

Ng, F. D. (2019) Instructional leadership. In H. Wong and F. D. Ng (eds.). School leadership and educational change in Singapore. Springer.

Ng, F. S. D., Nguyen, T. D., Wong, K. S. B., \& Choy, K. W. W. (2015). Instructional leadership practices in Singapore. School Leadership \& Management, 35(4), 388-407. https:// doi.org/10.1080/13632434.2015.1010501

Peacock, J. S. (2013). Making your own role: Exploring instructional leadership practice of high school science department chairs [Doctoral dissertation]. University of Georgia. https://getd.libs.uga.edu/pdfs/peacock_jeremy_s_201308_edd.pdf

Ritchie, S. M., Mackay, G., \& Rigano, D. L. (2006). Individual and collective leadership in school science departments. Research in Science Education, 36(3), 141-161. https:// doi.org/10.1007/s11165-005-9001-6

Robinson, V. M. J. (2010). From instructional leadership to leadership capabilities: Empirical findings and methodological challenges. Leadership and Policy in Schools, 9(1), 1-26. https://doi.org/10.1080/15700760903026748

Robinson, V. M. J., \& Timperley, H. S. (2007). The leadership of the improvement of teaching and learning: Lessons from initiatives with positive outcomes for students. Australian Journal of Education, 51(3), 247-262. https:// doi.org/10.1177/000494410705100303

Schmidt, M. (2000). Role theory, emotions, and identity in the department headship of secondary schooling. Teaching and Teacher Education, 16(8), 827-842. https://doi.org/10.1016/S0742-051X(00)00029-9

Seobi, B. A., \& Wood, L. (2016). Improving the instructional leadership of heads of department in under-resourced schools: A collaborative action learning approach. 
South African Journal of Education, 36(4), 1-14. http://dx.doi.org/10.15700/saje.v36n4a1326

Sherer, J. Z. (2008, March 27). Power in distributed leadership: How teacher agency influences instructional leadership practice. Paper presented at the AERA conference, 1-20. http:/ / citeseerx.ist.psu.edu/viewdoc/download?doi=10.1.1.307.6158\&rep=rep1 \&type $=\mathrm{pdf}$

Siskin, L. S. (1994). Realms of knowledge: Academic departments in secondary schools. Falmer Press.

Smith, C., Mestry, R., \& Bambie, A. (2013). Role players' experience and perceptions of heads of departments' instructional leadership role in secondary schools. Education as Change, 17(Sup1), S163-S176. https://doi.org/10.1080/16823206.2014.866001

South Africa. Department of Education (DoE). 2002. Revised National Curriculum Statement Grades R-9 (Schools). Government Printers.

Southworth, G. (2002). Instructional leadership in schools: Reflections and empirical evidence. School Leadership \& Management, 22(1), 73-91. https:// citeseerx.ist.psu.edu/viewdoc/download?doi=10.1.1.138.534\&rep=rep1 \&type $=$ pdf

Spillane, J. P., \& Hopkins, M. (2013) Organizing for instruction in education systems and school organizations: How the subject matters. Journal of Curriculum Studies, 45(6), 721-747. https://doi.org/10.1080/00220272.2013.810783

Spillane, J. P., Halverson, R., \& Diamond, J. B. (2001). Investigating school leadership practice: A distributed perspective. Educational Researcher, 30(3), 23-28. https:// doi.org/10.3102/0013189X030003023

Spillane, J. P., Halverson, R., \& Diamond, J. B. (2004). Towards a theory of leadership practice: A distributed perspective. Journal of Curriculum Studies, 36(1), 3-34. https:// doi.org/10.1080/0022027032000106726

Stein, M. K., \& Nelson, B. S. (2003). Leadership content knowledge. Educational Evaluation and Policy Analysis, 25(4), 423-448. https://doi.org/10.3102/01623737025004423

Stephenson, A. (2010). An examination of the issues facing heads of departments in New Zealand secondary schools [Master's thesis, Unitec Institute of Technology]. Unitec Institute of Technology Research Repository. https://hdl.handle.net/10652/1609

Timperley, H. S. (2005). Distributed leadership: Developing theory from practice. Journal of Curriculum Studies, 37(4), 395-420. https://doi.org/10.1080/00220270500038545

Turner, C., \& Bolam, R. (1998). Analysing the role of the subject head of department in secondary schools in England and Wales: Towards a theoretical framework. School Leadership \& Management: Formerly School Organisation, 18(3), 373-388. https://doi.org/10.1080/13632439869565

Umalusi, (2008). Learning from Africa: Science. A report of Umalusi's research comparing science syllabuses and examinations in South Africa with those in Ghana, Kenya and Zambia. Umalusi Council for Quality Assurance. https://www.umalusi.org.za/docs/research/2008/africa_science.pdf

Wanzare, Z. O. (2013). Skills and attributes of instructional supervisors: Experience from Kenya. Educational Research and Review, 8(24), 2270-2280. https://academicjournals.org/article/article1387885294_Zachariah.pdf

Weller, L. D. (2001). Department heads: The most underutilized leadership. NASSP Bulletin, 85(625), 73-81. https:// doi.org/10.1177/019263650108562508

Wise, C. (2000). Being a curriculum leader: Helping colleagues to improve learning. In H. Busher and A. Harris (eds.). Subject leadership and school improvement. Paul Chapman. 
York-Barr, J., \& Duke, K. (2004). What do we know about teacher leadership? Findings from two decades of scholarship. Review of Educational Research, 74(3), 255-316. https://doi.org/10.3102/00346543074003255

Zepeda, S., \& Kruskamp, B. (2007). High school department chairs: Perspectives on instructional supervision. The High School Journal, 90(4), 44-54. https://www.jstor.org/stable/40364192 